$$
\text { Conf } 941203-25
$$

\title{
A Solar Module Fabrication Process for Hale Solar Electric UAVs
}

\section{P.G. Carey, R.C. Aceves, N.J. Colella, and K.A. Williams Lawrence Livermore National Laboratory}

\author{
R.A. Sinton \\ Private Consultant \\ G.S. Glenn \\ Spectrolab, Inc.
}

\author{
Presented at \\ First World Conference on Photovoltaic Energy Conversion . \\ Waikoloa, Hawaii \\ December 5-9, 1994
}

December 12, 1994

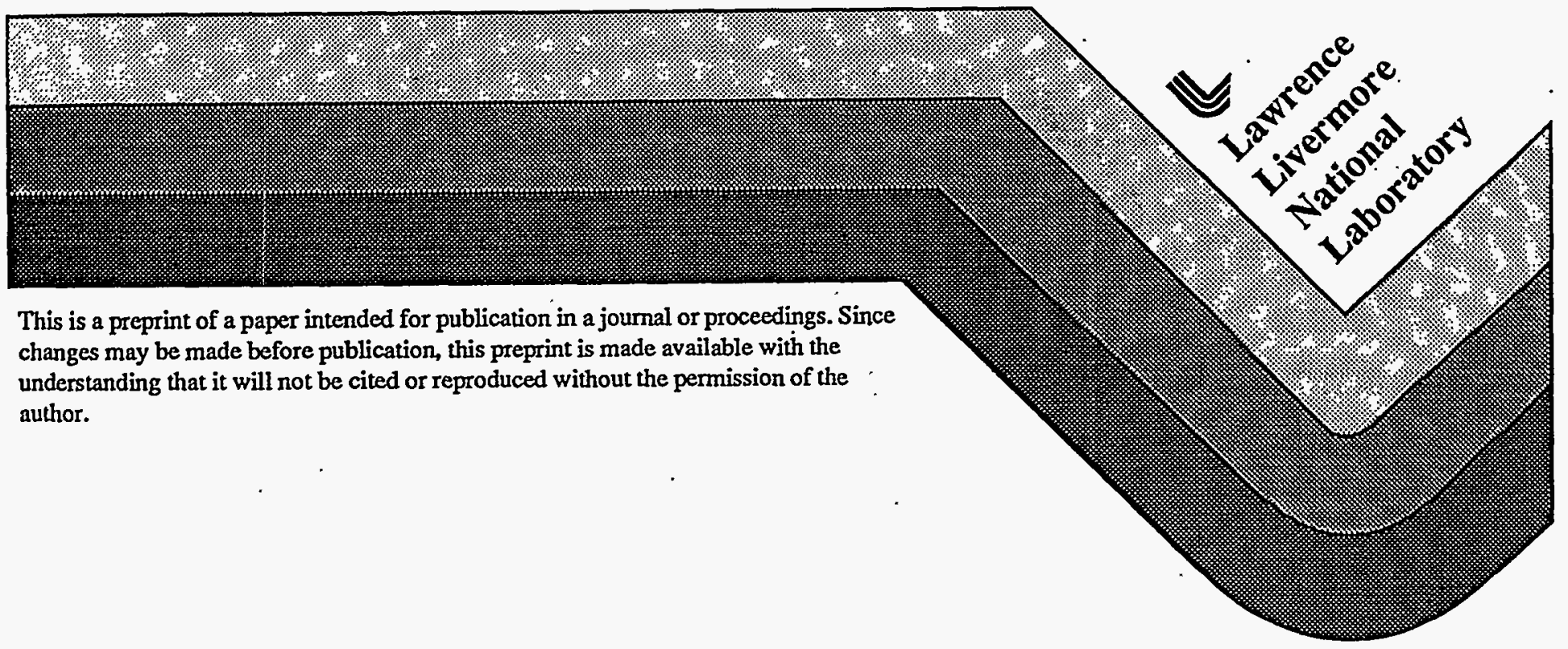

This is a preprint of a paper intended for publication in a journal or proceedings. Since changes may be made before publication, this preprint is made available with the understanding that it will not be cited or reproduced without the permission of the author. 


\section{DISCLAIMER}

This report was prepared as an account of work sponsored by an agency of the United States Government. Neither the United States Government nor any agency thereof, nor any of their employees, make any warranty, express or implied, or assumes any legal liability or responsibility for the accuracy, completeness, or usefulness of any information, apparatus, product, or process disclosed, or represents that its use would not infringe privately owned rights. Reference herein to any specific commercial product, process, or service by trade name, trademark, manufacturer, or otherwise does not necessarily constitute or imply its endorsement, recommendation, or favoring by the United States Government or any agency thereof. The views and opinions of authors expressed herein do not necessarily state or reflect those of the United States Government or any agency thereof. 


\section{DISCLAIMER}

Portions of this document may be illegible in electronic image products. Images are produced from the best available original document. 


\title{
A SOLAR MODULE FABRICATION PROCESS FOR HALE SOLAR ELECTRIC UAVS
}

\author{
P.G. Carey, R.C. Aceves, N.J. Colella, and K. A. Williams \\ Lawrence Livermore National Laboratory, P.O. Box 808, L-271, Livermore, CA 94551 \\ R.A. Sinton \\ Private Consultant, 4820 La Fiesta Place, San Jose, CA 95129 \\ G.S. Glenn \\ Spectrolab, Inc., 12500 Gladstone Ave., Sylmar, CA $91342-5373$
}

\begin{abstract}
We describe a fabrication process used to manufacture high power-to-weight-ratio flexible solar array modules for use on high-altitude-longendurance (HALE) solar-electric unmanned air vehicles (UAVs). These modules have achieved power-to-weight ratios of 315 and $396 \mathrm{~W} / \mathrm{kg}$ for $150 \mu \mathrm{m}$-thick monofacial and $110 \mu \mathrm{m}$-thick bifacial silicon solar cells, respectively. These calculations reflect average module efficiencies of $15.3 \%$ $(150 \mu \mathrm{m})$ and $14.7 \%(110 \mu \mathrm{m})$ obtained from electrical tests performed by Spectrolab, Inc. under $A M O$ global conditions at $25^{\circ} \mathrm{C}$, and inciude weight contributions from all module components. (solar cells, lamination material, bypass diodes, interconnect wires, and adhesive tape used to attach the modules to the wing): The fabrication, testing, and performance of $32 \mathrm{~m}^{2}$ of these modules will be described.
\end{abstract}

\section{INTRODUCTION}

A span-loaded flying-wing vehicle, known as the RAPTOR PATHFINDER, is being employed as a technology integration platform to enable high altitude long endurance flight [1]-[2] for weeks or months. It requires lightweight flexible solar modules able to endure mechanical stress and adverse environmental conditions. It therefore, presents a photovoltaic application that is intermediate to conventional low cost terrestrial installations and expensive space satellite installations. The airplane has a 30.5 meter wingspan with a 2.44 meter chord, and was originally built and flown in 1983 by AeroVironment, Inc. Flight altitudes exceeding 3.05 $\mathrm{km}$ were achieved at that time using $\mathrm{Ag} / \mathrm{Zn}$ batteries as the power source. The flight envelope of the original aircraft has been expanded for highaltitude flight through major upgrades to its structure and electric propulsion systems. In addition, the plane has been converted to solar electric powered flight by covering the upper wing skin with lightweight flexible solar array modules. First generation modules containing $350 \mu \mathrm{m}$ thick single crystal silicon solar cells were used to provide approximately one-half of the electrical power in a series of flight tests which took place between 10/93 and 1/94. This paper describes the development of a lightweight flexible solar array module fabrication process used on $32 \mathrm{~m}^{2}$ of second generation solar modules. These second generation modules contain both 110 and $150 \mu \mathrm{m}$ thick single crystal silicon solar cells. The combination of first and second generation modules to be flown on the Pathfinder wing for the high altitude flight tests is shown in Fig. 1. These tests are scheduled to begin in the spring of 1995.

\section{SOLAR CELL SELECTION AND DESCRIPTION}

The PATHFINDER airplane solar cell selection is a function of many parameters including the solar cell: (i) efficiency, (ii) weight, (iii) reliability, (iv) flexibility, (v) bifaciality, (vi) availability, and (vii) cost. In addition, the PATHFInDER wing dimensions are fixed at 30.5 by 2.44 meters, and solar modules cannot be mounted on the front $25 \%$ and rear $5 \%$ of the wing due to aerodynamic considerations. Thus, the maximum area available for solar module coverage is $(30.5 \mathrm{~m}) \times(2.44 \mathrm{~m}) \times$ $(0.7)=52.1 \mathrm{~m}^{2}$. Because of this limited area we have made the decision to use the most efficient, reasonably priced, and lightest weight solar cells available. The type of solar cell meeting all these criteria is single crystal silicon. Thin film $(<10 \mu \mathrm{m}$ thick) a-Si solar cells are very low cost but do not yet have.large area efficiencies high enough to justify their use in this application (see, for example [3]). Other promising thin film materials such as CdTe and CulnSe 2 [4]-[5] have shown 

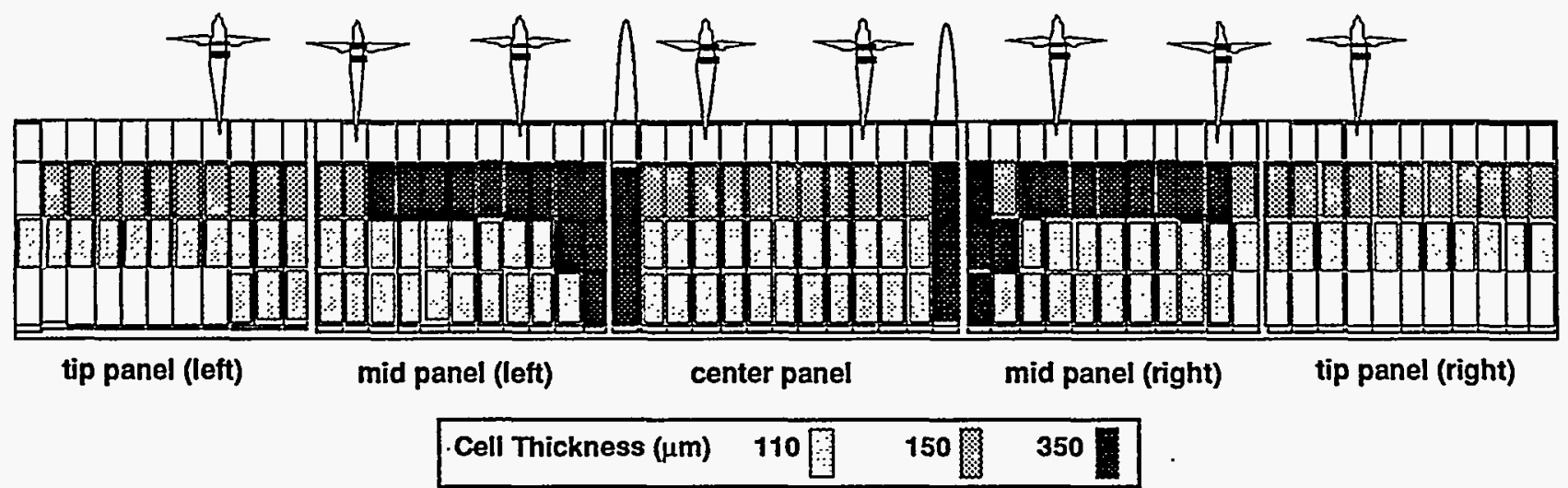

Fig. 1. PATHFINDER wing showing the solar module configuration for high altitude flight testing. Three single crystal silicon cell thicknesses are used, namely; 110,150 , and $350 \mu \mathrm{m}$. There are a total of $57 \mathrm{rib}$ bay sections, and the plane is divided into 5 sections namely, one center , 2 mid, and 2 tip panels.

impressive efficiencies for small area cells, but again do not yet have high enough efficiencies over large areas to be useful for this fixed wing application. GaAs and GaAs/Ge solar cells are very efficient and have less radiation degradation [6] but are too heavy and expensive. Very thin film GaAs cells [7] would be ideal except that they are again too costly and currently not available for large area applications.

Single crystal silicon. solar cells are suited for this application because of their relatively low cost and high efficiency. Since much of the PV industry is based on these type of cells, manufacturing costs have already scaled compared to the other technologies. Additionally; single crystal silicon cells are used in a wide variety of applications from major terrestrial installations with cell efficiencies of $14 \%$ (AM1.5 global) and costing in the $\$ 5 /$ Watt range, to solar race cars with cell efficiencies over 22\% (AM1.5) costing in the $\$ 100$ 's/Watt, to space satellite systems costing even more.

Silicon solar cells are also made in a wide variety of cell thicknesses depending on the application. The first generation cells used on the PATHFINDER test flights made from $10 / 93$ to $1 / 94$ used $350 \mu \mathrm{m}$ thick standard terrestrial single crystal solar cells made by Siemens Solar, Inc. Some of these solar panels will still be on the plane for the high altitude flights commencing in the spring 1995 time frame.

The second generation modules described in this work contain commercially available solar cells. The solar cells are made from single crystal $\mathrm{Cz}$ silicon that is thinned to $150 \mu \mathrm{m}$ for the monofacial cells and $110 \mu \mathrm{m}$ for the bifacial cells. Both are
Spectrolab type K-6 solar cells with diffused $A l$ and "1 $B$ implanted back surface fields for the mono- and bifacial cells, respectively. Average efficiencies for the $6.73 \mathrm{~cm} \times 6.98 \mathrm{~cm}$ solar cells are $15.7 \%$ for the $150 \mu \mathrm{m}$ cells and $15.0 \%$ for the $110 \mu \mathrm{m}$ cells (frontside illumination only). Bifacial response is desired for some of the solar modules because the transparent wing will transmit Albedo to the cell backsides.

\section{SOLAR ARRAY LAMINATE SELECTION}

The solar array laminate materials must be lightweight, highly transmissive, UV stable, and able to withstand the extreme temperatures seen at high altitudes. Fluoropolymers are ideally suited for this application because they are: virtually chemically inert, highly transmissive in the visible spectrum, dimensionally stable for temperatures between $-70^{\circ} \mathrm{C}$ to $107^{\circ} \mathrm{C}$, highly abrasion resistant, and exhibit very little UV degradation. Candidate polymer materials with these properties include the flouropolymers ethylenechlorotriflouroethylene (Halar ${ }^{\mathrm{N}}$ ) and polyvinylideneflouride (Tedlar ${ }^{\mathrm{TH}}$ ). Both of these flouropolymers have high melting temperatures $\left(>240^{\circ} \mathrm{C}\right)$, and low embrittlement temperatures $\left(<-72^{\circ} \mathrm{C}\right)$.

As part of the selection process we have performed experiments to determine the photovoltaic response versus incident angle for the two films laminated to solar cells with a silicone transfer adhesive (Dielectric Polymer Neltape 1001). The results of these experiments are shown in Fig. 2. The angular photoresponse of solar cells laminated to $12.5 \mu \mathrm{m}$ 


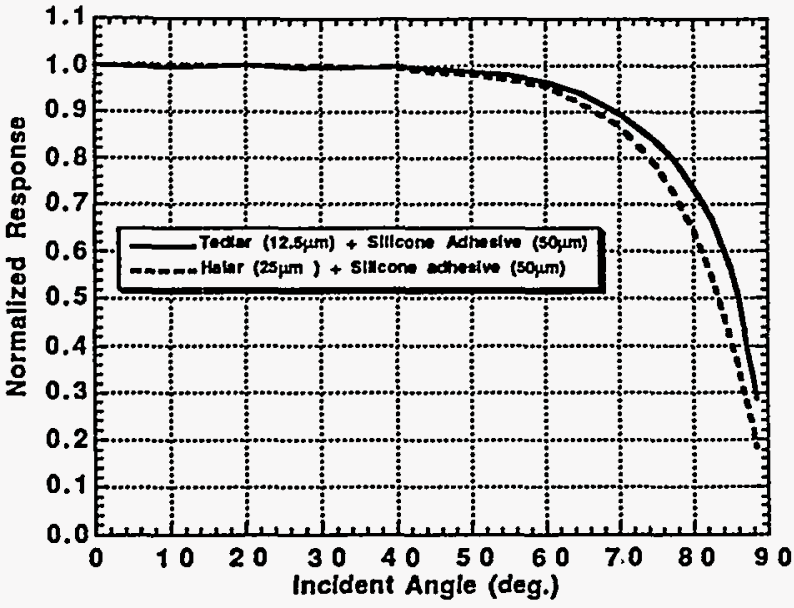

Fig 2. Normalized photovoltaic response vs. incident angle for Tedlar and Halar based laminates.

Tedlar is higher than for $25 \mu \mathrm{m}$ of Halar, making this material more suited for our application. This is because Tedlar has a higher transmission of lightfor $\lambda<700 \mathrm{~nm}$. In addition, the Tedlar is commercially available in thinner layers than the Halar, and modules made from these two laminates will have slightly different weights as shown in Fig. 3. These two results indicate that Tedlar is the best laminate material for this application.

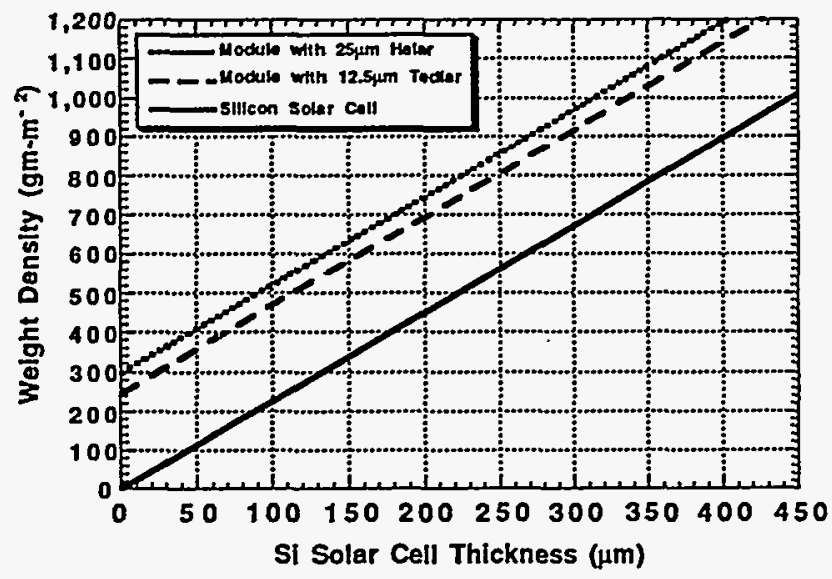

Fig. 3. Weight density vs. Si solar cell thickness ( $\mu \mathrm{m})$ for Si solar cells and modules made from the Tedlar and Halar laminate structures.

\section{SOLAR ARRAY LAMINATE STRUCTURE AND LAMINATION PROCESS}

The laminate structure itself consists of two flouropolymer Tedlar/silicone adhesive sandwiched layers that encapsulate the solar cells. The result is a sealed planar solar cell array laminate structure that protects the solar cells and provides additional stability on the top and bottom. We have chosen very thin layers of laminate and adhesive in order to fabricate a high power to weight ratio solar array modules. The Tedlar film is $12.5 \mu \mathrm{m}$, and the unsupported silicone adhesive film is $50 \mu \mathrm{m}$. Together they add up to $178 \mathrm{gm} / \mathrm{m}^{2}\left(0.036 \mathrm{lb} / \mathrm{ft}^{2}\right)$ for the top and bottom layers.

The module fabrication process involves laminating the electrically connected solar cells between the top and bottom Tedlar/silicone adhesive layers. This encapsulates the silicon solar cells as shown in Fig. 4. The process is best described by illustration (see Fig. 5). As the release liner is removed, the top and bottom laminate layers are fed between the laminating rollers. The electrically connected solar cells are then fed through the apparatus and sealed

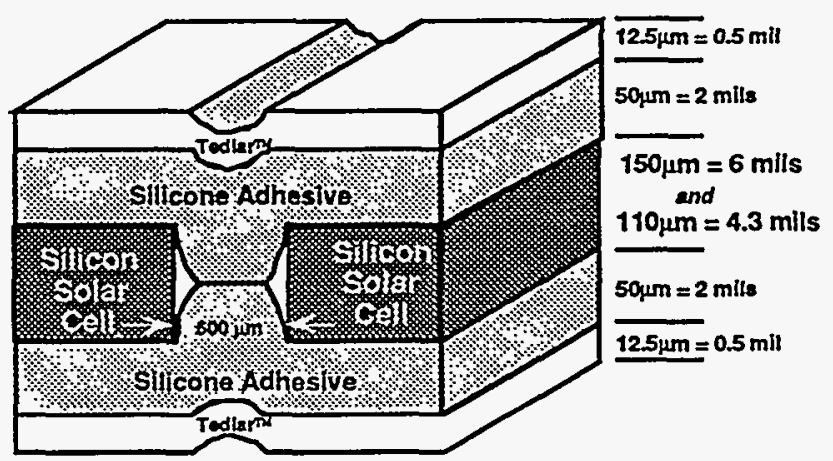

Fig. 4. Solar array module structure with sealed solar cells. Silicon solar cell thicknesses of $150 \mu \mathrm{m}$ ( $6 \mathrm{mil})$ and $110 \mu \mathrm{m}$ ( $4.3 \mathrm{mil})$ are used in this work.

by the top and bottom laminate layers. The cells pass through the apparatus twice. The first pass is at room temperature and causes the solar cells to be laminated to the top and bottom layers. The second pass is at $100^{\circ} \mathrm{F}\left(37^{\circ} \mathrm{C}\right)$ and causes the silicone adhesive layers to reflow and seal the solar array module. After electrical testing and sorting by $\mathrm{Isc}_{\mathrm{sc}}$, the submodules are attached to the PATHFINDER wing using Tedlar/silicone adhesive tape and vacuum bagging to insure uniform pressure.

\section{SUBMODULE DESCRIPTION AND PERFORMANCE}

The solar cells are interconnected into strings of 7 cells per row with $0.51 \mathrm{~mm}$ a spacing between cells and 8 rows per submodule ( 1 submodule $=7 \times 8$ array of cells) as shown in Fig. 6. Seven bypass diodes have been attached to heat sinking electrical 


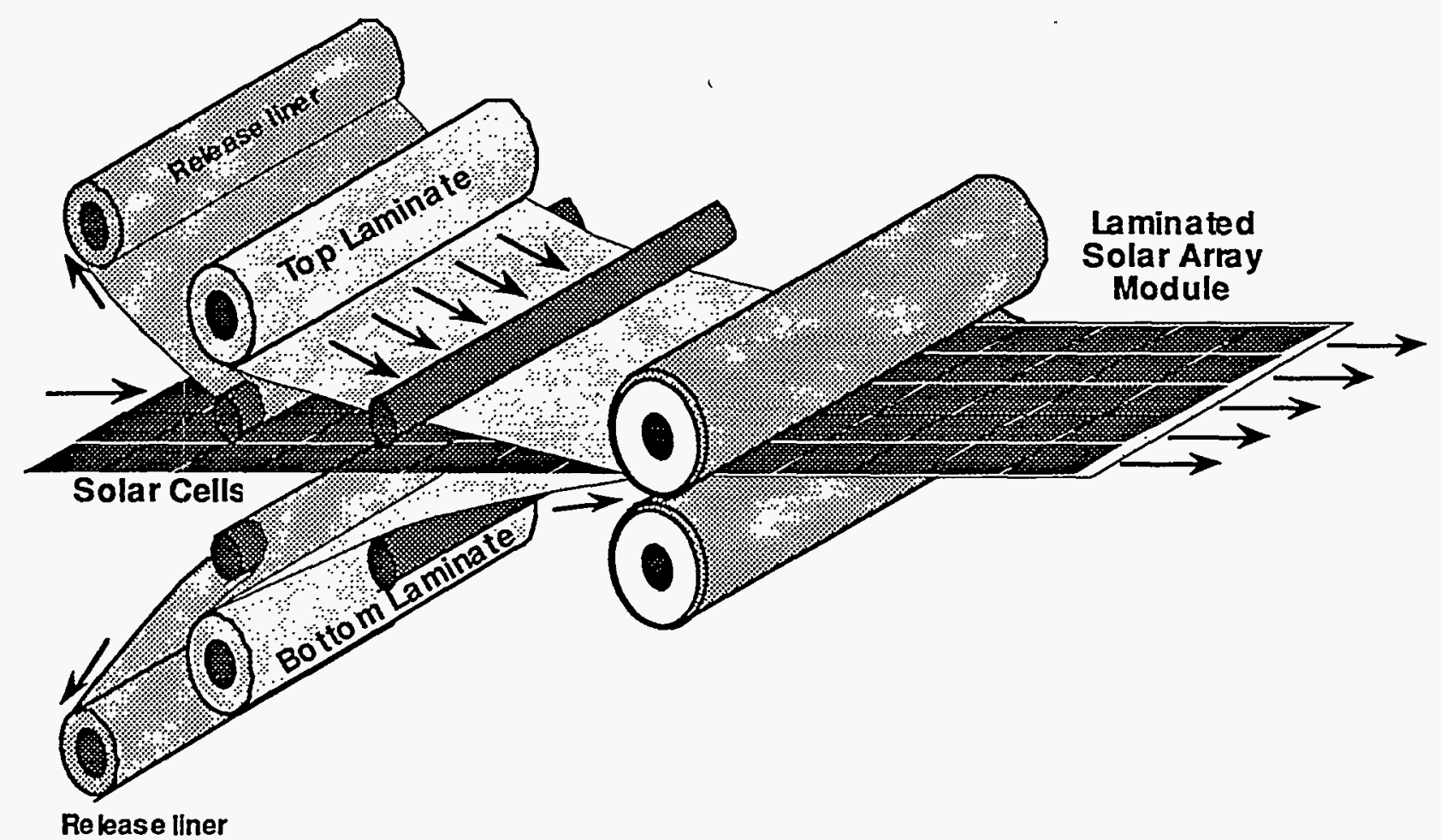

Fig. 5. Schematic of array lamination process. The polyethylene release liners are removed and the top and bottom laminate layers are fed to the laminating rollers. The electrically connected solar cells are then fed through the rollers to laminate them into a solar array module.

tab leads and soldered into both sides of each submodule for redundant protection against open circuit failures. These diodes are very small $(2 \mathrm{~mm} \times 2 \mathrm{~mm})$, thin $(350 \mu \mathrm{m})$ and are rated for $V_{B}=-40 \mathrm{~V}$ and $l_{F}=3 A$.

The solar cell interconnects have been chosen to have low resistance while being lightweight and flexible. We use $25 \mu \mathrm{m}$ thick $\mathrm{Ag}$ etched-mesh interconnects which electrically interconnect the solar cells along each edge. Modules made using these interconnects have been mechanically tested in our wing stress simulation apparatus. This apparatus simulates PATHFINDER take off, landing, and up to a $5 \mathrm{~g}$ load on the wing by subjecting the module to $\pm 0.115 \mathrm{~cm}$ tension-compression cycles over a 51 $\mathrm{cm}$ rib bay section. This is the predicted worst case dimensional change expected for the flexible PATHFINDER airplane. No electrical or open circuit failures due to broken solar cells and/or interconnects have been observed after over 20,000 tension/compression cycles. These submodules are thus flexible enough under predicted worst case conditions to withstand PATHFINDER flight. Each submodule has an aperture area of $47.3 \mathrm{~cm} \mathrm{x}$

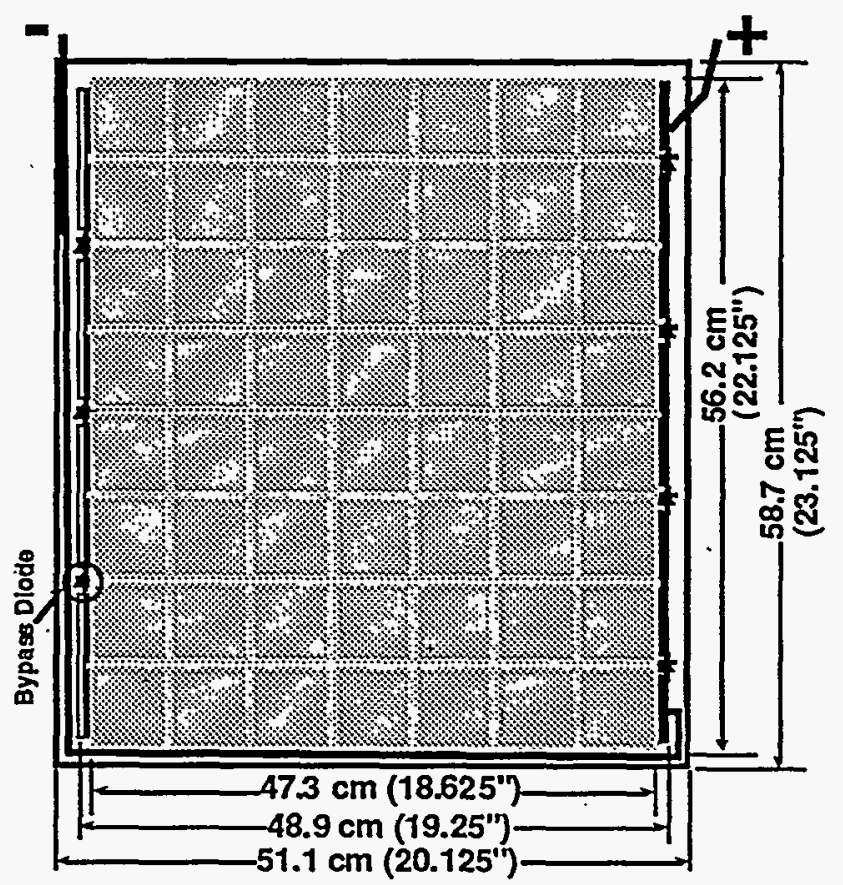

Fig. 6. Schematic of PATHFINDER submodule showing the $7 \times 8$ cell array, bypass diode locations, and dimensions. 
$56.2 \mathrm{~cm}\left(0.268 \mathrm{~m}^{2}\right)$. The corresponding average aperture-area efficiencies as measured by Spectrolab under AMO global $\left(25^{\circ} \mathrm{C}\right)$ testing conditions are $15.3 \%$ and $14.7 \%$ (frontside illumination only) for the Type I and II solar cells, respectively. A summary of the submodule electrical characteristics is shown in Table I. Here we see that the maximum power voltage for each

Table I. Submodule electrical performance.

\begin{tabular}{|l|c|c|}
\hline Solar Cell Type & $\begin{array}{c}\text { Type I } \\
\text { monofacial }\end{array}$ & $\begin{array}{c}\text { Type II } \\
\text { bifacial }\end{array}$ \\
\hline Cell Thickness ( $\mathrm{mm})$ & 150 & 110 \\
\hline $\begin{array}{l}\text { Average AMO submodule } \\
\text { efficiency (\%) }\end{array}$ & 15.29 & 14.76 \\
\hline Submodule Voc (V) & 34.91 & 34.70 \\
\hline Submodule Isc (A) & 2.073 & 2.062 \\
\hline Submodule Vmp (V) & 28.34 & 27.59 \\
\hline Submodule Imp (A) & 1.949 & 1.933 \\
\hline Average Fill Factor & 0.7637 & 0.7453 \\
\hline
\end{tabular}

submodule is approximately $28 \mathrm{~V}$. In order to achieve the desired bus voltage of $>100 \mathrm{~V}$, we must interconnect the submodules into groups of 4 in series to make what we call a module. For the sake of clarification, submodules are laminated individually, and modules are comprised of 4 series connected submodules having a total operating voltage of $\approx 112 \mathrm{~V}$.

The submodule weights and electrical performance for the two types of solar cells is shown in Table II. Here we see that very high power to weight ratios are obtained with these modules with 315 and 396 W/kg for the Type I and II solar cells, respectively.

Table II. Submodule powers and weights.

\begin{tabular}{|l|c|c|}
\hline Solar Cell Type & $\begin{array}{c}\text { Type I } \\
\text { monofacial }\end{array}$ & $\begin{array}{c}\text { Type II } \\
\text { bifacial }\end{array}$ \\
\hline Cell Thickness ( $\mathrm{mm})$ & 150 & 110 \\
\hline $\begin{array}{l}\text { Solar Cell + Interconnect } \\
\text { Weight (gm) }\end{array}$ & 118.20 & 77.30 \\
\hline $\begin{array}{l}\text { Total submodule } \\
\text { weight (gm) }\end{array}$ & 175.60 & 134.70 \\
\hline $\begin{array}{l}\text { Total AM0 Power } \\
\text { Frontside Only (Watts) }\end{array}$ & 55.25 & 53.34 \\
$\begin{array}{l}\text { Power to Weight Ratio } \\
\text { Frontside Only (Watts/kg) }\end{array}$ & 315 & 396 \\
\hline $\begin{array}{l}\text { Additional bifacial power } \\
\text { from 15\% Albedo (Watts) }\end{array}$ & 0.00 & 8.00 \\
\hline $\begin{array}{l}\text { Power to Weight Ratio } \\
\text { with 15\% Albedo } \\
\text { (Watts/kg) }\end{array}$ & 315 & 455 \\
\hline
\end{tabular}

If we add the bifacial component expected for the Type II cells ( $15 \%$ Albedo), we obtain a power to weight ratio of $455 \mathrm{~W} / \mathrm{kg}$. Actual power to weight ratios for the submodules will be better than this because of the low operating temperatures expected in the 12,000 to 24,000 meter (40$80,000 \mathrm{ft}$.) altitude range predicted for PATHFinder during its spring 1995 test flights.

We have simulated the average cell temperature and maximum solar power versus altitude for the Type II (110 $\mu \mathrm{m}$ bifacial) solar cells taking into consideration the curvature of the wing surface. The results are summarized in Fig. 7 (a-c). In (a)
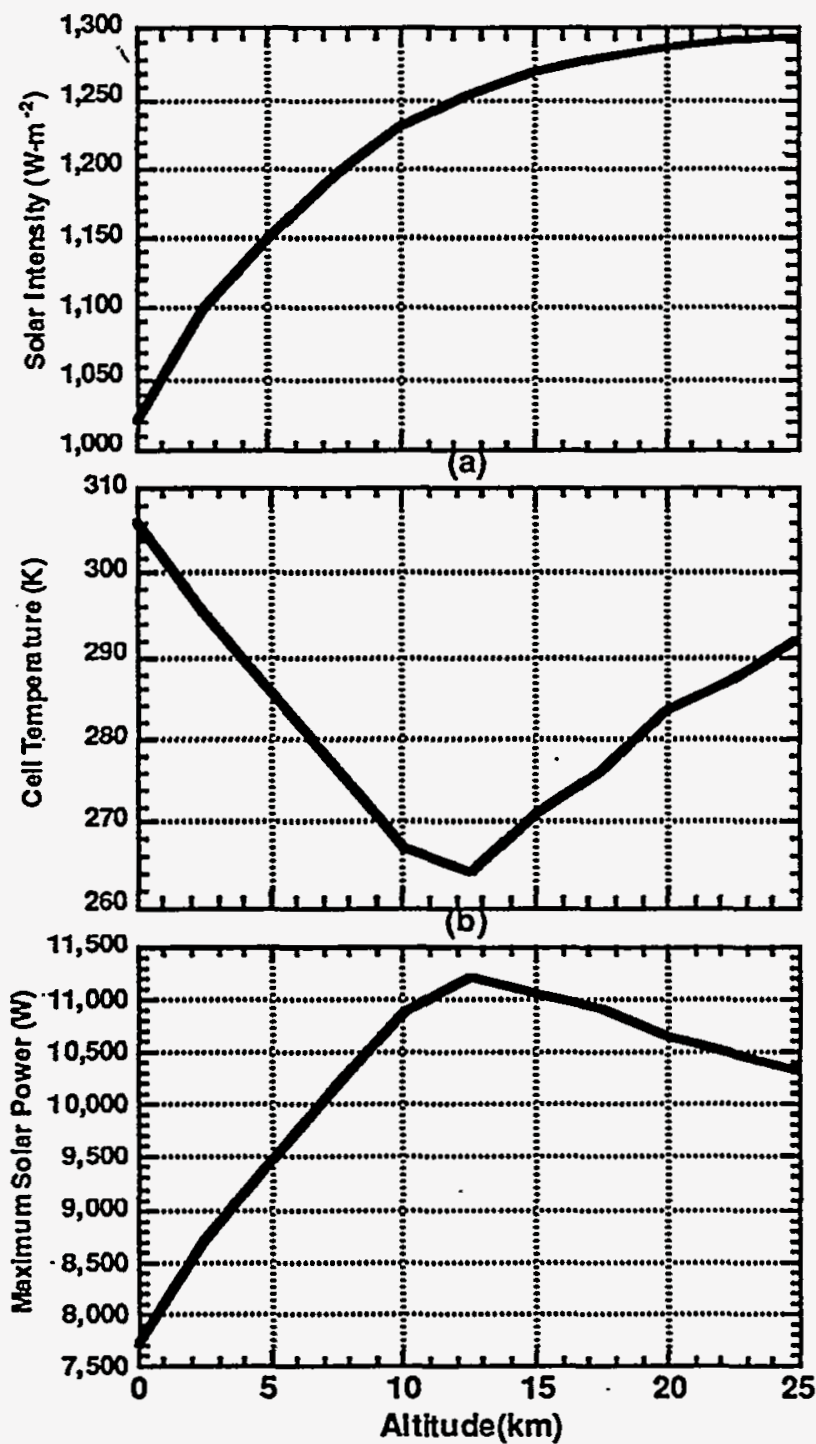

(c)

Fig. 7. Simulation of solar intensity, cell operating temperature, and maximum solar power versus altitude

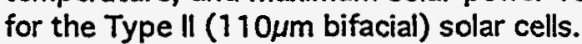


the solar intensity versus altitude is shown. In (b) the average cell temperature is calculated using estimates for radiative and convective cooling and the experimentally determined value for $\alpha$ of 0.62 . This low value of $\alpha$ coupled with the average efficiency $\eta=0.147$ results in a corresponding low temperature of operation determined by $[\alpha-\eta]=$ 0.473 . The minimum cell operating temperature of $264 \mathrm{~K}\left(-9^{\circ} \mathrm{C}\right)$ occurs at an altitude of approximately $12.5 \mathrm{~km}$. At higher altitudes the air pressure continues to drop and ability for the cells to cool decreases. An increase in the solar cell operating temperature is predicted. In (c) the maximum solar power versus altitude is shown. It continues to increase with altitude due to solar irradiation increasing and cell operating temperature decreasing. At $12.5 \mathrm{~km}$ the maximum power begins to slightly decrease with altitude due to the increase in cell operating temperature.

\section{PATHFINDER PERFORMANCE}

The actual solar array to be flown on PATHFINDER in the spring of 1995 contains the number of cells and modules shown in Table III. Of the total number of solar cells (8730), 2016 are Spectrolab Type I, 4704 are Spectrolab Type II, and 2010 are Siemens terrestrial type cells from the generation one type of module. The total number of rib bays covered is 40.05 out of a possible 57, and the total area of the array is $40.4 \mathrm{~m}^{2}$. The solar array weight considering all modules, interconnects, and tape is $27.6 \mathrm{~kg}$ which represent $13 \%$ of the total plane weight.

Table III. Actual PATHFINDER solar array for spring 1995 test flights.

\begin{tabular}{|l|c|c|c|c|}
\hline \multicolumn{1}{|c|}{ Solar Cell Type } & $\begin{array}{c}\text { Type I } \\
\text { monofacial }\end{array}$ & $\begin{array}{c}\text { Type II } \\
\text { bifacial }\end{array}$ & $\begin{array}{c}\text { Siemens } \\
\text { monofacial }\end{array}$ & otals \\
\hline Cell Thickness $(u \mathrm{~m})$ & 150 & 110 & 350 & \\
\hline $\begin{array}{l}\text { Total number } \\
\text { of solar cells }\end{array}$ & 2016 & 4704 & 2010 & 8730 \\
\hline $\begin{array}{l}\text { Total number of } \\
\text { submodules }\end{array}$ & 36 & 84 & 26 & 146 \\
\hline $\begin{array}{l}\text { Total number } \\
\text { of modules }\end{array}$ & 9 & 21 & 8 & 38 \\
\hline $\begin{array}{l}\text { Total number of } \\
\text { rib bays covered }\end{array}$ & 12 & 28 & 10.05 & 40.05 \\
\hline $\begin{array}{l}\text { Total area of } \\
\text { modules (m²) }\end{array}$ & 9.6 & 22.5 & 8.3 & 40.4 \\
\hline $\begin{array}{l}\text { Tolal weight } \\
\text { of modules (kg) }\end{array}$ & 11.3 & 6.3 & 10.0 & 27.6 \\
\hline
\end{tabular}

Using the actual solar array allows the altitude versus time of day to be predicted for PATHFINDER. The simulation takes into account all parameters affecting flight, including solar array power, total plane weight, motor efficiency, sun angle, propeller efficiency, air density, etc... versus altitude. In Fig. 8 we show the predicted altitude versus time of day for PATHFINDER assuming that the date is July 20 and the take off point is at $35^{\circ} \mathrm{N}$ latitude (e.g. Edward's AFB, CA). We see that for a 0700 take off time the plane will climb steadily until it reaches a maximum altitude of $23.8 \mathrm{~km}$ at around 1400 hours. At this point the amount of solar power available is not enough to overcome the reduced lift supplied by the $3 \%$ of an atmosphere present at this altitude and the plane flies approximately level. Note the plane's altitude goes slightly higher and lower at this point because it is flying in a station keeping pattern which will point the array away from the sun during part of the time. At 1800 hours the plane is brought down in order to land before dark.

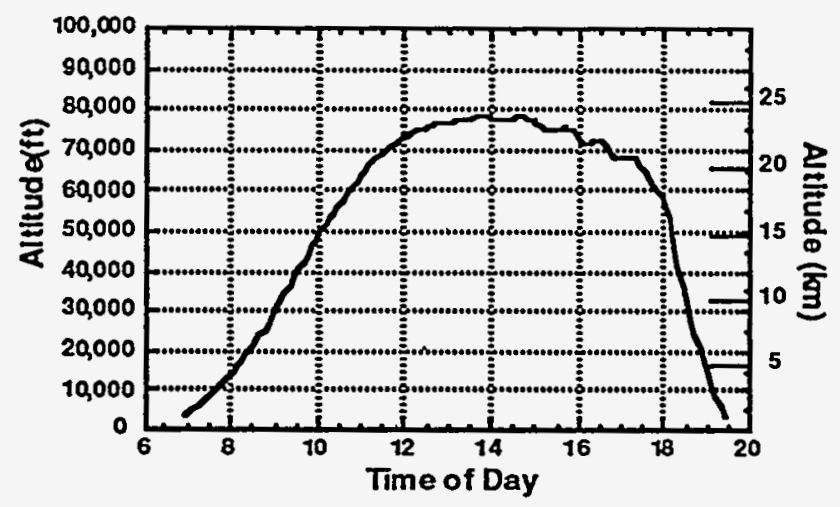

Fig. 8. Simulation of PATHFINDER altitude vs. time of day using the actual solar array containing the submodules fabricated for this work and earlier modules fabricated by Siemens. A maximum altitude of $23.8 \mathrm{~km}(78,000 \mathrm{ft}$.) is predicted.

\section{SUMMARY}

We have developed an array lamination process to fabricate high power-to-weight ratio solar modules suitable for high altitude unmanned air vehicles such as the PATHFInDER. This process involves: (i) electrically interconnecting the solar cells with a flexible interconnect, (ii) soldering bypass diodes along both sides to protect against open circuit failures, and (iii) laminating the resulting solar cell array between two Tedlar/silicone adhesive sandwiched layers. The laminate materials, Tedlar and silicone, have been chosen to minimize UV degradation, withstand the extreme thermal variations imposed by long-endurance high-altitude flight, and accommodate the flexing of the wing. The modules have achieved $315 \mathrm{~W} / \mathrm{kg}$ (150 $\mu \mathrm{m}$ 
Spectrolab Type I) and $390 \mathrm{~W} / \mathrm{kg}(110 \mu \mathrm{m}$ Spectrolab Type 11). Since the wing material is transparent, a $15 \%$ Albedo will boost the power to weight ratio to $455 \mathrm{~W} / \mathrm{kg}$ for submodules containing the Type II bifacial cells.

\section{ACKNOWLEDGMENTS}

The work was performed under the auspices of the U.S. Department of Energy under Contract W-7405Eng-48. The authors would like to thank Bart Hibbs of AeroVironment for the altitude simulations and Mark Cohen, Jim Daley, Bob Curtin, and Ray Morgan of AeroVironment, Inc. for valuable insights, discussions, and suggestions.

\section{REFERENCES}

[1] D.W. Hall, C.D. Fortenbach, E.V. Dimiceli, and R.W. Parks, "A Preliminary Study of Solar Powered Aircraft and Associated Power Trains," NASA Contractor Report 3699, Dec. 1983.

[2] F. Mitlitsly, N.J. Colella, and B. Myers, " Unitized regenerative fuel cells for solar rechargeable aircraft and zero emission vehicles," LLNL UCRL-JC-117130, Dec. 1994.

[3] W. Luft, B. von Roedern, B. Stafford, and L. Mrig, "Second Controlled Light-Soaking Experiment for amorphous silicon modules," Proceedings of the 23rd IEEE Photovoltaic Specialists Conference, Louisville, KY, May 1993, pp. 860-866.

[4] K. Zwiebel, H.S. Ullal, B.G. von Roedern, R. Noufi, T.J.. Coutts, and M.M. Al-Jassim," Perspectives and Opportunities in polycrystalline thin-film photovoltaic technologies," Proceedings of the 23rd IEEE Photovoltaic Specialists Conference, Louisville, KY, May 1993, pp. 379-387.

[5] B.M. Ba şol, V.K. Kapur, A. Halani, A. Minnick, and C. Leidholm, "Modules and flexible cells of CulnSe $e_{2}$, Proceedings of the 23rd IEEE Photovoltaic Specialists Conference, Louisville, KY, May 1993, pp. 426-430.
[6] L.W. Silfer, Jr.," Timed-H, an ideal application for GaAs/Ge solar cells" Proceedings of the 23rd IEEE Photovoltaic Specialists Conference, Louisville, KY, May 1993, pp. 1330-1332.

[7] J. Geis and J.H. Arnold, "Photovoltaic electric power applied to unmanned aerial vehicles (UAV)" in the Proceedings of the SPRATT Conference, NASA Lewis, June 1994. 